\title{
View on Public Diplomacy to Research and Develop Villa Culture in Lushan Mountain
}

\author{
Peng Chen \\ Economics and Management School \\ Jiujiang University \\ Jiujiang, China \\ jjucp@qq.com
}

\author{
Yaojun $\mathrm{Yu}$ \\ Teaching Affairs Office \\ Jiujiang University \\ Jiujiang, China \\ yyj168@126.com
}

\begin{abstract}
Lushan is a world famous mountain. Architectural culture, especially the modern villas, testifies the truth of western countries' invasion of China, and mixes Western and Chinese culture. Moreover, it's a great work of Western architectural art and Chinese construction technology. Owing to its world cultural value, Lushan villas are the most important component of world cultural heritage. Public Diplomacy is one manner to promote the "soft power" of a country, which attracts more and more concerns. The thesis, on the view of public diplomacy, researches villa culture in Lushan Mountain to advance the development of Lushan culture and public diplomacy.
\end{abstract}

As a diplomatic practice, public diplomacy appeared in China as early as the Spring and Autumn Period and in ancient Greece. But until recently it has attracted a growing number of scholars to do some theoretical research. Nowadays, public diplomacy is valued in more and more countries as an important part of country's soft power. Professor Zhao Qizheng says that public diplomacy is activities of a national government, civil society and social organizations designed to enhance their image or reputation, increase activity of friendly relations among nations. It includes government acts against the public in other countries, public acts against the governments in other countries and public acts against the public in other countries. The essence of public diplomacy is the cultural exchange and transmission of information and ideas. [1] We can say that the public diplomacy of China is to make foreign countries know and understand Chinese culture.

Keywords—Public Diplomacy, Villa Culture, Lushan Mountain, Research and Develop

\section{LUSHAN IS A WORLD FAMOUS MOUNTAIN, ALSO A MOUNTAIN OF PUBLIC DIPLOMACY}

Lushan is a famous scenic spot in China, which lies in the northern part of Jiangxi Province and near the Yangtze River and Poyang Lake, China's largest freshwater lake. Lushan is a mountain of nature, politics, religions; it is also a cultural mountain. Lushan's inclusive cultural resources and unique human resources get a high rating in international communities. In December 1996, Lushan Mountain was included in the "World Heritage Lists" as a "world cultural landscape". UNESCO noted that Lushan has a special and universal value, and it deserves protections for the benefit of all mankind. [2]

From the beginning of the last century to the mid, there have been thousands of foreign nationals living long-term in
Lushan. There were many schools set up by Americans, Frenchmen, British men and Russians. Many western children are been subjected to a combination of Chinese and Western education model in Lushan. So far, there still is a Kuling School Alumni Association in the United States. In recent years, the International Schools in Lushan mainly recruit foreign children to accept the Chinese-style education. Chinese cultures spread through this kind of education, and make the foreign public learn more about our country.

In recent years, with the rise of China's national strength, the international influence of Lushan also increases rapidly. On October 14 2009, representatives of 12 world famous mountains including Mount Gambier in Australia, Mount Hood in United States, Chocolate Hills in Philippines, etc gathered in Lushan and declared the foundation of World Famous Mountains Association. The association would carry out more extensive cooperation in mountain protection, tourism development and science popularization. They decided to set the headquarters in Lushan. After that, the World Famous Mountains Association absorbed 16 new members all over the world. And

In May 2013, the First World Famous Mountains Research Symposium \& College Public Diplomacy Forum was held at Jiujiang University. Experts and scholars from the United States, Australia, Brazil, Germany, Russia, Japan and other 15 countries and international organizations attended the forum and discussed how to use the college academic advantages for the study world famous mountains, how to strengthen exchanges and cooperation between universities located near world famous mountains, and how to promote public diplomacy and cross-cultural research. This conference achieved fruitful results.

Therefore, Lushan has been at the forefront of the country's famous mountains and rivers in foreign exchange. It is the vanguard of the mountains and rivers on promoting public diplomacy.

\section{VILLA CULTURE OF LUSHAN}

Lushan has many international performances; one of them is Lushan Villa culture. We can say that the history of Lushan villa is the history of Lushan's opening to the world. Lushan villas are a typical representative of the cultural landscape of Lushan. Villas in Lushan mix among the natural beauty, and 
form a cultural landscape with high aesthetic value, which makes Lushan unique among the famous mountains in China.

\section{A. Historical Origins of Lushan Villa Culture}

Lushan still retains thousands of villas built before 1940's. These villas represent different cultures of the United Kingdom, France, Germany, United States, Russia, Italy, Finland, Netherlands, Austria, and Japan. They have a reputation as "the world's House Museum". One of them is "Meilu" villa of the Chiang Kai-shek couple, which becomes one of the most famous tourist sites of Lushan. In addition, Lushan East Valley Modern villas are closely related with many Chinese and foreign celebrities. There are many moving historical stories happening there.[3]

In 1880's, Edward Selby Little, a young missionaries from the United Kingdom, developed the world's unique natural leisure summer resort with beautiful scenery and pleasant climate - China Kuling. From then to the early time of 20th century, more than 500 villas representing different countries were built there, and Kuling became synonymous of Lushan.[4]

On December 4, 1926, Chiang Kai-shek went to Kuling in a sedan chair for the first time. After that, many dignitaries and tycoons followed. They all bought villas and lived there, and Kuling was regarded as the Summer Capital of the National Government. A lot of important events in the modern history of China happened there, and Kuling enjoyed quite a reputation.

On June 29, 1959, for the first time, Mao Zedong came to and liked Lushan, where he held three important meetings in 1959, 1961 and 1970. During each meeting, party and state leaders and provincial leaders all lived in the Villas.

\section{B. Features of Lushan villa culture}

\section{1) World culture value}

As a part of the world's cultural heritage, Lushan villa culture has the world's cultural value. The modern architecture, especially the Lushan villa culture is the main content of the world's natural and cultural landscape when Lushan was inscribed on the World Heritage List. The Lushan villa culture was highly rated by United Nations experts. It is an important part of our cultural heritage and also a valuable part of the world's cultural heritage.

\section{2) Artistic styles}

Lushan villas have a variety of artistic styles. Lushan modern villas were built by more than 20 countries. Different styles coexist in one same valley, become a worldwide villas Museum. This is a unique cultural phenomenon in modern world history.

\section{3) Historical meaning}

Lushan Villa culture is an important witness in modern Chinese culture foreign exchange. Lushan modern architecture re closely linked with Chinese modern history, events, domestic and foreign important figures. From European missionaries' arriving at Lushan in1880s to three Lushan Conferences in the1960s and197, historical changes in China left a deep imprint to Lushan Villas.

\section{4) Local characteristics}

Lushan villas architectural style is of simplicity and abstinence. Architects used local building materials, and the villas are of local characteristics. The modern architecture in Lushan is not as elegant and gorgeous as villas in coastal areas. The architectural beauty of Lushan is the same as its natural beauty. Their characteristics are simple, natural, rough and heavy. They may not recruit much attention, but they have rich contents and heavy heritages. Therefore, many great scholars and politicians have a special liking for Lushan villas, whose beauties are our real pursuit and can resonate with our hearts.

\section{5) Design and size}

Because of the rational design and compact size, Lushan villas seem to be precious and decent [5]. Although Meilu villa, the building area of 996 square meters, two floors, neither prominent nor luxurious, halls nor rooms are not large, it won the Mao Zedong and Jiang Jieshi's favorite. Modern Architecture in Lushan is well known for its size, quality and design. The golden ratio or geometric ratio makes the building look elegant as well as classical legacy.

\section{6) Combination with gardens}

Each villa is with a garden, combining with each other. The formation and development of Modern Architecture in Lushan, as Kuling, are impacted by the British utopian socialism. Owing to the basic features of modern garden city, Lushan villas are the earliest works of genius and unique architectural achievement.

\section{7) Entirety and individuality}

Combination between the overall plan and the individual architecture. There was a complete and systematic planning and layout for Lushan Kuling, designed by British engineer Bo Heer in 1896. The overall construction is neat, but no rule or connection among individuals, which are extremely rare in the world. [6]

\section{The DeVeloping Strategy of Lushan Villa Cultural}

Culture is one nation's unique deposit and witness of long history. Cultural tourism resources is a combination of cultural landscape and the natural landscape, not only enabling people to enjoy handsome magnificent mountain scenery, but also being able to understand the profound ancient culture. Currently, the Lushan tourist routes already contains a small amount of celebrity villas attractions, such as the Meilu villas, the First Lulin villas, which can mobilize the interest of tourists, attract tourists to visit these mystery villas, and understand the long history culture of Lushan.

\section{A. To open up celebrity Villa Tourism.}

The unusual route is focused on east-west oriented valley, where was located some representative celebrity villas. Tourists explore mysterious and long stories of villas; feel the rich culture and history of Lushan. The role of route is to increase the content of Lushan tourism, enrich connotation of Lushan culture, and solve the problem of the current tourism over- concentrated. 


\section{B. To build the world Lushan Villa Park}

At present, there are some issues in the Lushan villas utilization, such as low economic value, less protection. Therefore, we should increase the investment of protection; improve their economic efficiency, so that the protection and use of villas are able to enter a virtuous circle. The feasibility of constructing the world Lushan Villa Park is based on historical and emotional value of the villas, the role of identity, historical continuity and religious worship. Then the park is redeveloped as modern buildings, given new mission and meaning, and injected new economic power, so as to promote the development of the Lushan tourism.

\section{To found a Lushan Villa Museum}

To select a beautiful villa located in East Valley as "Lushan villa Museum" or "Lushan Art Museum of Modern Architecture”. The villa is displayed in the museum by scaled down sand table model. Through multimedia tools such as sound, light, electricity, visitors may know about full description of the formation and development of Lushan villa, including the time of the planning and implementation of thought, various treaties or regulations, historical photographs, and relations between celebrity and villa, etc. All of those facilitate visitors understanding the villa from sensibility to rationality.

\section{To hold international conferences and events}

The head quarter of the World Famous Mountains Association is in Lushan. Lushan should play its role by means of extensively organizing various international seminars, souvenir fairs, ancient architectural photography exhibition and other activities. In addition, full cooperation with friendly countries is carried out in mountains protection, tourism development, and popularization of science etc. Such as the First Famous World Symposium of Research and Universities Public Diplomacy Forum was held in Jiujiang University in 2013.

Culture is the most attractive selling point in tourism. The villa culture should be regarded as a new bright spot to develop, combining culture and tourism together and playing the role of culture in tourism, which will be able to enhance "soft power" of Lushan scenic area, then to attract more tourists at home and abroad. At the same time, tourists will stay in Lushan for more days, and promote consumption, which becomes a new growth pole of Lushan tourist economy. Consequently, tourists not only enjoy more schedule of tourism, but gain more knowledge of history.

\section{REFERENCES}

[1] Zhao Qizheng, the Necessity to Strengthen Public Diplomacy of China, Journal of Shenyang Normal University (Social Science Edition), Vol.33, pp.1-2,2003(In Chinese)

[2] Ouyang Huailong and Ouyan Xian, Architectural culture of Lushan, South Architecture, Vol. 04, pp.36-42, 2003(In Chinese)

[3] Li Wenming, Study on Deep Development of the Lushan Tourism Culture, Central South University of Forestry and Technology(Thesis for the Degree of Master), pp.21-22, 2004(In Chinese)

[4] DAI Ying and ZENG Ke-feng,The Tourism Exploitation of Villa-cluster Resource in Lushan Mountain, Areal Research and Development,Vol.25, pp.68-71,2006(In Chinese)

[5] Chen Yanjun, The Case Research on Protection and Renewal of Frontage Building in Lushan Kuling Street, Huazhong University of Science \& Technology(Thesis for the Degree of Master), pp.23-24, 2013(In Chinese)

[6] Ouyang Xian, Comparative Study of Lushan Kuling villas and villas in Gulangyu, South Architecture , Vol. 04, pp.62-65, 2002(In Chinese) 